\title{
ANALYSIS OF MENOPAUSAL WOMEN'S PERCEPTION TOWARD SIGNS AND SYMPTOMS OF MENOPAUSE
}

\author{
Diah Retno Utami, Santi Wahyuni \\ Program Studi D III Keperawatan Cirebon - Poltekkes Kemenkes Tasikmalaya \\ Correspondence: daffa_keisha@yahoo.com
}

\begin{abstract}
Menopausal women experience physical and hormonal changes so that it often causes problems. This study is generally to identify menopausal women's perception toward signs and symptoms of menopause in Kalijaga which is claimed as the village with the highest number of menopausal women in Cirebon. This study used descriptive quantitative research by applying the cross-sectional approach. The population of this study was women aged 45-55 years which were chosen using purposive sampling technique. Menopause Rating Scale (MRS) was used as the instrument of the study. The data were analyzed using descriptive analysis. The findings showed that there were some signs and symptoms experienced by the respondents namely hot flushes and sweating $(90.7 \%)$, heart discomfort (46.4\%), sleep problems $(72.2 \%)$, depressive mood $(70.1 \%)$, irritability $(76.3 \%)$, anxiety $(75.3 \%)$, physical and mental exhaustion $(80.4 \%)$, sexual problems $(58.8 \%)$, bladder problems $(71.1 \%)$, vaginal dryness $(74.2 \%)$, joint and muscular discomfort $(89.7 \%)$. The symptoms had different levels of severity and include all three dimensions. In addition, Most of the respondents had negative perceptions toward the signs and symptoms of menopause. Based on the result of the study, it can be concluded that the respondents experience eleven signs and symptoms of menopause at varying scales of severity. It is suggested for the respondents to recognize the signs and symptoms of menopause and utilize health services in order to address the problems due to the signs and symptoms of menopause. It is also recommended for the respondents to follow elderly health programs.
\end{abstract}

Keywords: Menopause, Perception, Signs, and Symptoms.

\section{INTRODUCTION}

Women experience physical and psychological changes as a result of the aging process including menopause condition. All women in the world experience some problems during the menopause period; $17 \%$ of them experience severe symptoms, $34 \%$ experience mild symptoms, and 49\% feel moderate symptoms (WHO, 2005). The study conducted by Rahman (2010) in Malaysia showed that the most problems experienced by the women at perimenopause and postmenopause are joint and muscular discomfort (80.1\%), physical and mental exhaustion (67.1\%), and sleep problems (52.2\%). The other research which is conducted in Bangladesh (2011) revealed that most of the women in menopause period experience exhaustion $(92.90 \%)$ a headache $(88.80 \%)$, sleep problems (54.4\%), and mood swing (depression) (37.3\%). 
Various physical, psychological, and hormonal changes which are experienced by menopausal women cause some problems such as hot flushes and sweating, irritability, anxiety, sexual problems, bladder problems, joint and muscular discomfort, and vaginal dryness. Every woman experiences different signs and symptoms so that it is required to conduct a study to know the signs and symptoms that are generally experienced by menopausal women. It is expected to help the healthcare to be able to give the right counseling to the menopausal women.

Cirebon's population is 304,343 (BPS Kota Cirebon, 2014). Based on age and gender, the population in Cirebon in 2013 includes 10,040 of women aged 45-49 years, 8,911 of women aged 50-54 years, and 7,131 of women aged 55-59 years. The preliminary study showed that from 5 sub-districts in Cirebon, Harjamukti is the highest number of population. It consists of 3,929 of women aged 45-49 years, 3,561 of women aged 50-54 years, and 2,962 of women aged 55-59 years. The highest number of menopausal women in Harjamukti sub-district is Kalijaga village that is 3,011 which includes 1,184 of women aged 45-49 years, 978 women aged 50-54 years, and 849 of women aged 55-59 years.

The general purpose of this study is to identify the respondents' perception toward signs and symptoms of menopause. Specifically, it is to analyze the signs and symptoms of menopause, the menopause signs and symptoms mostly experienced by the respondents, the most disturbing sign and symptom experienced by the respondents, to identify the dimension of menopausal signs and symptoms, and also to analyze the perception of the respondents toward the signs and symptoms of menopause. 


\section{METHODS}

The design of this study was descriptive quantitative research by applying the crosssectional approach. The population of this study was 3,011 of women aged 45-55 years in Kalijaga village Cirebon which were chosen using purposive sampling technique. The number of samples was determined using Slovin's formula (cited in Notoatmojo, 2010) i.e. $\mathrm{n}=\mathrm{N} / 1+\mathrm{N}\left(\mathrm{d}^{2}\right)$. The purposive sampling technique used inclusive and exclusive criteria. The inclusive criteria cover the respondent domiciled in Kalijaga, willing to be the respondent, and able to read and write. Then, the exclusion criteria included verbal communication difficulties and memory problems.

The data of this study were gathered using instrument namely Menopause Rating Scale (MRS). The MRS has been validated by the psychometrics regulation and firstly established in Germany. The MRS consists of 11 items (complaint or symptoms). The scale has a scoring system which is based on the severity of the symptoms felt. The scale starts from 0 for no complaints/severity 0 until 4 for very severe symptoms. The respondents provided their personal perception by checking one of the possible boxes of severity for each item.

In order to know the characteristics of the subjects and count the frequency distribution and proportion, the data were analyzed using a descriptive method. The respondents' perceptions were analyzed by counting the mean of the answers from the questionnaire using a Likert scale (none, mild, moderate, severe, and very severe) and then counting the percentage. 


\section{RESULTS}

The respondents involved in this study were 97 participants. Table 1 presents the descriptive analysis which covers the age of menarche, education level, and occupation.

Table 1 The Frequency Distribution of Respondents Based on Respondents' Characteristics

\begin{tabular}{cccc}
\hline No & Respondent's Characteristics & Frequency (n) & Percentage (\%) \\
\hline 1. & Age of Menarche & & \\
& $<9$ years old & 1 & 1.0 \\
$10-14$ years old & 67 & 69.1 \\
& $>15$ years old & 29 & 29.9 \\
\hline 2. & Education Level & & \\
& Primary (SD) & 96 & 99.0 \\
& Secondary ( SMP and SMA) & 0 & 0 \\
& Tertiary (College/University) & 1 & 1.0 \\
\hline 3. & Occupation & & \\
& Work & 17 & 17.5 \\
& Not work & 80 & 82.5 \\
\hline
\end{tabular}

$\mathrm{n}=$ total, $\%=$ Percentage

Table 1 indicates that most of the respondents started to menstruate (menarche) at age 10-14 years $(69.1 \%)$. The age of menarche is related to the age of menopause. The study conducted by Senolinggi (2015) at North Sulawesi proved that the earlier the menarche the later the menopause.

Most of the respondents' education level was primary (99.0\%). There was only one respondent which has the tertiary level of education. Education is an important factor which supports someone's ability to understand information easier. Having adequate education would shape mindset, perception, and also the attitude in making a decision. In term of occupation, the respondents are mostly housewives which spend most their daily activities at home and interact less with a wide environment so that they aren't exposed by a lot of information including information related to health problems and menopause. 


\section{Respondents' Perception toward Signs and Symptoms of Menopause}

The respondents of this study had different perception toward signs and symptoms of menopause. They also had various complaints about the signs and symptoms of menopause. It presents in the following table.

Table 2 The Frequency Distribution of Respondents Based on Signs and Symptoms of Menopause

\begin{tabular}{clccccc}
\hline \multirow{2}{*}{ No } & \multicolumn{1}{c}{ Perception } & \multicolumn{5}{c}{ Total (Percentage \%) / Scale } \\
\cline { 3 - 6 } & & None & Mild & Moderate & Severe & $\begin{array}{c}\text { Very } \\
\text { Severe }\end{array}$ \\
\hline 1. & Hot flushes and sweating & $9(9.3)$ & $8(8.2)$ & $28(28.9)$ & $35(36.1)$ & $17(17.5)$ \\
2. & Heart discomfort & $52(53.6)$ & $20(20.6)$ & $14(14.2)$ & $10(10.3)$ & $1(1.1)$ \\
3. & Sleep problems & $27(27.8)$ & $29(29.9)$ & $17(17.5)$ & $17(17.5)$ & $7(7.2)$ \\
4. & Depressive Mood & $29(29.9)$ & $35(36.1)$ & $21(21.6)$ & $11(11.3)$ & $1(1.0)$ \\
5. & Irritability & $23(23.7)$ & $40(41.2)$ & $23(23.7)$ & $10(10.3)$ & $1(1.0)$ \\
6. & Anxiety & $24(24.7)$ & $29(29.9)$ & $25(25.8)$ & $15(15.5)$ & $4(4.1)$ \\
7. & Physical and mental & $19(19.6)$ & $30(30.9)$ & $22(22.7)$ & $19(19.6)$ & $7(7.2)$ \\
& exhaustion & & & & & \\
8. & Sexual problems & $40(41.2)$ & $29(29.9)$ & $15(15.5)$ & $9(9.3)$ & $4(4.1)$ \\
9. & Bladder problems & $28(28.9)$ & $35(36.1)$ & $18(18.6)$ & $12(12.4)$ & $4(4.1)$ \\
10. & Vaginal dryness & $25(25.8)$ & $40(41.2)$ & $22(22.7)$ & $7(7.2)$ & $3(3.1)$ \\
11. & Joint and muscular & $10(10.3)$ & $25(25.8)$ & $18(18.6)$ & $13(13.4)$ & $31(32)$ \\
& discomfort & & & & \\
\hline
\end{tabular}

It can be inferred from table 2 that most of the respondents $(90.7 \%)$ experience hot flushes and sweating symptom, even $36.1 \%$ of them experience it in a very severe level. This condition can cause an uncomfortable condition that may disturb the sleep quality of the respondents. It is in line with a study conducted by Rahman (2011) in Bangladesh involved 509 participants which showed that hot flushes and sweating is felt by $35.8 \%$ respondents. When this sign and symptom occur, women's neck and face will be sweating and it causes rashes on the chest's skin (Atikah, 2010). Generally, this condition happens for several months or a year before and after the menstruation stop. Hot flushes occur as the increase of blood flow in the blood vessel of face, neck, chest, and back. Skin's color turns into red and warm and it is also sweaty on the night. 
The respondents who feel heart discomfort were $46.4 \%$ in which $20.6 \%$ of them felt it in mild level, $14.4 \%$ in the moderate level, $10.3 \%$ in severe level, and $1.1 \%$ in very severe level. The majority of the respondents $(56.3 \%)$ did not have experience this symptom since they did sport regularly at Puskesmas (public health care in Indonesia). Rahman's study (2011) at Bangladesh revealed that 19.1\% of respondents experienced heart discomfort.

Heart discomfort such as palpations is caused by reducing of estrogen levels which affect the heart works. According to Ngastina (2013), this condition is related to the menopause because decreasing of estrogen hormone would influence the health of the heart. Moreover, Ronny (2013) emphasized that the estrogen hormone protects the hearth from coronary heart disease, maintains HDL cholesterol level, and decreases LDL cholesterol level. Estrogen hormone can repair the endothelial function of the blood vessel and relax the smooth muscle of the artery. Estrogen hormone can prevent the damage of blood vessel wall and the increasing of blood pressure. At menopause period, the advantages of estrogen go down so that the mortality rate of women caused by coronary heart disease increases rapidly.

Most of the respondents (72.2\%) had sleep problem in which $29.9 \%$ experience it in mild level. Varied complaints included having difficulty to start sleeping, unpleasant sleep, and always wake up in the very early morning. In line with that, the study done by Santhi Vadugu and Vani Lanke (2015) in India showed that $65.7 \%$ of menopausal women had sleep problems symptom. The sleep problem is caused by the uncomfortable feeling as the effect of hot flushes and sweating occurring at night. As a result, it affects the quality of respondents' sleep. 
Sleep problems mostly happened to the menopausal women as a result of hot flushes and the sudden intense sensation of needing to go the toilet to urinate at night. Some women feel hard to sleep i.e. having difficulty to start sleeping or always wake up in the very early morning. Sleep problems also can be caused by the decrease of serotonin levels in premenopause (Atikah, 2010). Serotonin plays a role as a neurotransmitter. More than 40 millions of brain cells' activities are influenced by serotonin directly or indirectly. Serotonin which is widely distributed influences not only someone' psychological condition but also someone' body functions. The serotonin functions in the brain are to regulate someone's mood and desires, hunger, body temperature, and drowsiness (Lunetta Yoshe, 2012). The decrease of serotonin levels occurred at menopause also affects the sleep problems.

Most of the respondents $(70.1 \%)$ experienced depressive moods with varying degrees of severity. $36.1 \%$ of the respondents were at a mild level. Some respondents thought that their body's condition at menopause was different from before they get menopause. They did not feel as strong/health as before. Depressive moods are occurred due to the decline of estrogen levels and the decrease of neurotransmitter in the brain which affects the mood swings. Besides, the respondents are anxious to be left by their husband as they feel they are not sexually productive anymore, and they feel the anxiety to face the death,

The result is quite similar to the study conducted by Vadugu and Lanke (2015) in India showing that most of the respondents (60\%) experience depressive moods. According to Atikah (2010), the decrease of estrogen level affects the neurotransmitter in brain i.e. dopamine, serotonin, and endorphin. Dopamine plays a role to regulate emotion, body immune systems, and sexuality. Serotonin's role is to control mood and 
sleep-wake behavior. Endorphin function is related to memory and feeling about pain. The decrease of estrogen levels is associated with the reduced dopamine, serotonin, and endorphin's production. Furthermore, it can cause memory problems and mood swings or fractious.

Most of the respondents in this study $(76.3 \%)$ had irritability problems. $41.2 \%$ of them felt it in mild level, $23.7 \%$ of them in the moderate level, $10.3 \%$ of them in severe level, and $1.1 \%$ of them in very severe level. Rahman's study (2010) in Malaysia confirmed that $37.9 \%$ of the participants have irritability problems. Atika (2010) said that irritability at menopausal women is caused by the falling of estrogen levels in blood so that it affects the reduction of dopamine, serotonin, and endorphin's production. This condition makes problems such as memory problems and mood swings or fractious appear.

The majority of the respondents (75.3\%) felt anxiety. $29.9 \%$ of them felt it in mild level, $25.8 \%$ of them in the moderate level, $15.5 \%$ of them in severe level, and $4.1 \%$ of them in very severe level. Anxiety felt is caused by the afraid feeling of something worse that will happen in the future such as disease and death. It is in line with the study done by Rahman (2010) in Malaysia which proved that $36.5 \%$ of the respondents experienced the anxious feeling. The decrease of estrogen hormone causes the decrease of the neurotransmitter in the brain. The neurotransmitter in the brain influences human's moods. Therefore, while the neurotransmitter levels are low, it will make the anxiety feeling appear which then it will cause depressive or stress mood (Atikah, 2010).

Most of the respondents $(80.4 \%)$ felt physical and mental exhaustion problem at the different level of severity. $30.9 \%$ of them feel it in mild level, $22.7 \%$ of them in the 
moderate level, $19.6 \%$ of them in severe level, and $7.2 \%$ of them in very severe level. The respondents experience physical and mental exhaustion in mild level since this complaint did not disturb their activities. Rahman's research (2010) in Malaysia proved that most of the participants $(67.1 \%)$ have physical and mental exhaustion problems. Physical and mental exhaustion is caused by the decrease of estrogen and progesterone levels. Physical and mental exhaustion often appears as the women hormonal changes especially estrogen hormone (Atika, 2010).

Most of the respondents (58.8\%) had sexual problems such as a lack of sexual desire, sexual activity changes, and sexual satisfaction changes. $29.9 \%$ of them experience it in a mild level, $15.5 \%$ of them feel it in the moderate level, $9.3 \%$ of them in severe level, and $4.1 \%$ of them in very severe level. The sexual problems occurred due to the reduced vaginal elasticity and lubrication. This result is similar to the study conducted by Rahman (2011) in Bangladesh which showed that $31.2 \%$ of the respondents experienced sexual problems. Based on Atikah (2010), dyspareunia or painful feeling during sex is caused by thinning of vagina's wall, reduced elasticity, thinning of epithelial cells which cause pain during or after sex because of poor lubrication. Some factors are also related to the lack of sexual desire or libido at menopausal women such as depression, sleep problems, and sweating at night.

The majority of the respondents $(71.1 \%)$ have bladder problems in varying level of severity. $36.1 \%$ of them feel it in mild level. It is different from the result's study by Rahman (2011) in Bangladesh which showed that only small numbers of participants $(12.8 \%)$ who have bladder problems. This problem can be caused by the muscle's weakness on the bladder so that most women have difficulties to hold urine in a long time, leaking of urine due to coughing, sneezing, laughing, and walking. This symptom 
occurs due to urogenital vaginal atrophy and urethra coming from the same embryonic tissues. Thus, estrogen deficiency can cause atrophy in those both of tissues. The effect of the estrogen deficiency in the urethra and bladder is associated with urethral syndromes such as frequency, urgency, and dysuria (painful urination) (Atikah, 2010).

The results of this study also showed that most of the respondents $(74.2 \%)$ had vaginal dryness problems such as a dry or a burning feeling and painful intercourse. This complaint is mostly felt in mild level (41.2\%) since the respondents admit that they have infrequent intercourse after entering elderly life. Therefore, they felt the symptom once in a while and it didn't disturb their activities. However, $22.7 \%$ of the respondents felt the complaint at the moderate level, $7.2 \%$ of them in severe level, and $3.1 \%$ of them it is very severe level. This result is in line with the study conducted by Rahman (2010) in Malaysia which confirmed that $37.9 \%$ experienced vaginal dryness. The vaginal dryness is caused by the falling of vaginal lubricants so that it leads to an increased risk of vaginal infection and painful feeling. Vaginal dryness occurs due to falling estrogen levels. Infection can be occurred due to vaginal dryness (Atikah, 2010).

Joint and muscular discomfort is felt by the most of the respondents $(89.7 \%)$ in varied scales of severity. $32 \%$ of them were in very severe level. Moreover, they say that the symptom is frequently occurred and disturb their activities. Joint and muscular discomfort occurs due to the diminution of bone density. As Rahman's study (2010) in Malaysia showed that joint and muscular discomfort is a sign and symptom which is mostly felt by the participants $(80.1 \%)$. The disappearance of bone density at menopause period causes the stiffness of joints. The disappearance of bone mass is started at 30 years old and faster at menopause period so that it increases the risk of 
osteoporosis. A broken bone caused by osteoporosis mostly occurs at corpus vertebrae. As a result, this condition inflicts a back pain (Linda J and Danny J, 2006).

\section{Respondents' Perception toward the Menopause Signs and Symptoms Mostly}

\section{Experienced by Them}

The following table presents the frequency distribution of signs and symptoms which mostly experienced by the respondents.

Table 3 Frequency Distribution of Signs and Symptoms of Menopause which are Mostly Experienced by the Respondents

\begin{tabular}{clcccccc}
\hline \multirow{2}{*}{ No } & Signs and Symptoms of & \multicolumn{2}{c}{ Yes } & \multicolumn{2}{c}{ No } & \multicolumn{2}{c}{ Total } \\
\cline { 3 - 8 } & Menopause & $\mathbf{n}$ & $\mathbf{\%}$ & $\mathbf{n}$ & $\mathbf{\%}$ & $\mathbf{n}$ & $\mathbf{\%}$ \\
\hline 1. & Hot flushed and sweating & 88 & 90,7 & 9 & 9,3 & 97 & 100 \\
2. & Heart discomfort & 45 & 46,4 & 52 & 53,6 & 97 & 100 \\
3. & Sleep problems & 70 & 72,2 & 27 & 27,8 & 97 & 100 \\
4. & Depressive Mood & 68 & 70,1 & 29 & 29,9 & 97 & 100 \\
5. & Irritability & 74 & 76,3 & 23 & 23,7 & 97 & 100 \\
6. & Anxiety & 73 & 75,3 & 24 & 24,5 & 97 & 100 \\
7. & Physical and mental exhaustion & 78 & 80,4 & 19 & 19,6 & 97 & 100 \\
8. & Sexual problems & 57 & 58,8 & 40 & 41,2 & 97 & 100 \\
9. & Bladder problems & 69 & 71,1 & 28 & 28,9 & 97 & 100 \\
10. & Vaginal dryness & 72 & 74,2 & 25 & 25,8 & 97 & 100 \\
11. & Joint and muscular & 87 & 89,7 & 10 & 10,3 & 97 & 100 \\
\hline \multicolumn{2}{r}{ Total } & 286 & 26,8 & 781 & 73,2 & 97 & 100 \\
\hline
\end{tabular}

$\mathrm{n}=$ total, $\%=$ Percentage

Table 3 displays that the menopause signs and symptoms mostly experienced by the respondents were hot flushed and sweating (90.7\%). Hot flushes and sweating are normal signs and symptoms of menopause. It occurs as the increase of blood flow in the blood vessel of face, neck, chest, and back. The study was done by Rahman (2010) in Malaysia involved 356 participants proved that hot flushes and sweating is felt by 41.6\% respondents. Hot flushes are commonly felt started from face to neck. Women's neck and face will be sweating and it causes rashes on the chest's skin. This condition happens for several months or a year before and after the menstruation stop. As 
discussed above, hot flushes occur as the increase of blood flow in the blood vessel of face, neck, chest, and back. Skin's color turns into red and warm, it is also sweaty excessively on the night, and heart has the palpitation.

\section{Respondents' Perception toward the most disturbing Signs and Symptoms}

Signs and symptoms of menopause that is considered as the most disturbing signs and symptoms are analyzed based on the complaints experienced by the respondents in very severe scale. The data is presented in the following table.

Table 4 Frequency Distribution of Disturbing Signs and Symptoms of Menopause According to Respondents' Complaints

\begin{tabular}{clcc}
\hline No & Signs and Symptoms of Menopause & Frequency $(\mathbf{n})$ & Percentage $(\%)$ \\
\hline 1. & Hot flushed and sweating & 17 & 21,2 \\
2. & Heart discomfort & 1 & 1,2 \\
3. & Sleep problems & 7 & 8,8 \\
4. & Depressive Mood & 1 & 1,2 \\
5. & Irritability & 1 & 1,2 \\
6. & Anxiety & 4 & 5,0 \\
7. & Physical and mental exhaustion & 7 & 8,8 \\
8. & Sexual problems & 4 & 5,0 \\
9. & Bladder problems & 4 & 5,0 \\
10. & Vaginal dryness & 3 & 3,8 \\
11. & Joint and muscular & 31 & 38,8 \\
\hline \multicolumn{2}{c}{ Total } & 80 & 100 \\
\hline
\end{tabular}

$\mathrm{n}=$ total, $\%=$ Percentage

The table 4 showed that 80 respondents $(82.47 \%)$ experience varied signs and symptoms of menopause in very severe scale. The most disturbing signs and symptoms experienced by the respondents was joint and muscular discomfort (38.8\%). This condition really disturbs the respondents since it affected their daily activities or in other words, it decreases their productivity. The activities were house tasks like laundry, washing dishes, preparing meals/cooking, cleaning and tidying up home, and etc. 
Joint and muscular discomfort occurs as the decrease of estrogen levels. Ridianti (2016) said that estrogen has an important role in bone metabolism such as decreasing the bone cells turnover so that it helps to push the bones to have strong mineral density. That role begins to fall after women entering the menopause period. Furthermore, women estrogen levels will be decreased because of the diminution of bone mineral density. This condition makes women at risk of osteoporosis. This is in line with Linda J and Danny J (2006) who said that estrogen protects bones so that if someone has low estrogen levels, it will make someone at risk of osteoporosis.

The result about signs and symptoms which mostly disturbs the respondents in this study is similar to the study of Shahedur Rahman (2011) in Bangladesh which showed that joint and muscular discomfort is experienced by most of the respondents (76.2\%). The stiffness of joints is caused by the disappearance of bone density at menopause period (Linda J and Danny J, 2006). The disappearance of bone mass is started at 30 years old and faster at menopause period so that it increases the risk of osteoporosis. A broken bone caused by osteoporosis has mostly occurred at corpus vertebrae. That is why it inflicts a low back pain. The least of calcium intake at pra menopause can increase the risk of osteoporosis at the menopause period. According to the study conducted by Londono et.al. (2013) in Colombia, Menopause is a factor causing osteoporosis especially to women aged above 45 years and have malnutrition history or low birth weight.

\section{Perception toward Signs and Symptoms Based on Its Dimension}

Eleven signs and symptoms of menopause can be categorized into three dimensions (ZEG Berlin, 2008). The first dimension is psychological symptoms in the 
scale of 1 to 16 (4 signs and symptoms: depressive mood, irritability, anxiety, and physical and mental exhaustion). The second dimension is some-vegetative symptoms on a scale of 1 to 16 (4 signs and symptoms: hot flushes and sweating, heart discomfort, sleep problems, and joint and muscular discomfort). The third dimension is urogenital symptoms on a scale of 1 to 16 (3 signs and symptoms: sexual problems, bladder problems, and vaginal dryness).

According to those dimensions, the data from the respondents present in table 5 .

Table 5 Frequency Distribution of Signs and Symptoms of Menopause Dimensions

\begin{tabular}{|c|c|c|c|c|c|c|c|c|c|c|}
\hline \multirow{2}{*}{ Dimension } & \multicolumn{2}{|c|}{ None } & \multicolumn{2}{|c|}{ Mild } & \multicolumn{2}{|c|}{ Moderate } & \multicolumn{2}{|c|}{ Severe } & \multicolumn{2}{|c|}{$\begin{array}{c}\text { Very } \\
\text { Severe }\end{array}$} \\
\hline & $\mathbf{n}$ & $\%$ & $\mathbf{n}$ & $\%$ & $\mathbf{n}$ & $\%$ & $\mathbf{n}$ & $\%$ & $\mathbf{n}$ & $\%$ \\
\hline \multicolumn{11}{|l|}{ Psycological Symptoms } \\
\hline Depressive Mood & 29 & 29,9 & 35 & 36,1 & 21 & 21,6 & 11 & 11,3 & 1 & 1,0 \\
\hline Irritability & 23 & 23,7 & 40 & 41,2 & 23 & 23,7 & 10 & 10,3 & 1 & 1,0 \\
\hline Anxiety & 24 & 24,7 & 29 & 29,9 & 25 & 25,8 & 15 & 15,5 & 4 & 4,1 \\
\hline Physical and mental exhaustion & 19 & 19,6 & 30 & 30,9 & 22 & 22,7 & 19 & 19,6 & 7 & 7,2 \\
\hline Total & 95 & & 134 & & 91 & & 55 & & 13 & \\
\hline \multicolumn{11}{|l|}{ Somato-Vegetative Symptoms } \\
\hline Hot flushes, sweating & 9 & 9,3 & 8 & 8,2 & 28 & 28,9 & 35 & 36,1 & 17 & 17,5 \\
\hline Heart discomfort & 52 & 53,6 & 20 & 20,6 & 14 & 14,2 & 10 & 10,3 & 1 & 1,1 \\
\hline Sleep problems & 27 & 27,8 & 29 & 29,9 & 17 & 17,5 & 17 & 17,5 & 7 & 7,2 \\
\hline Joint and muscular discomfort & 10 & 10,3 & 25 & 25,8 & 18 & 18,6 & 13 & 13,4 & 31 & 32,0 \\
\hline Total & 98 & & 82 & & 77 & & 75 & & 56 & \\
\hline \multicolumn{11}{|l|}{ Urogenital Symptoms } \\
\hline Sexual problems & 40 & 41,2 & 29 & 29,9 & 15 & 15,5 & 9 & 9,3 & 4 & 4,1 \\
\hline Bladder problems & 28 & 28,9 & 35 & 36,1 & 18 & 18,6 & 12 & 12,4 & 4 & 4,1 \\
\hline Vaginal dryness & 25 & 25,8 & 40 & 41,2 & 22 & 22,7 & 7 & 7,2 & 3 & 3,1 \\
\hline Total & 93 & & 104 & & 55 & & 28 & & 11 & \\
\hline
\end{tabular}

$\mathrm{n}=$ total, $\%=$ Percentage

Those three dimensions of signs and symptoms of menopause experienced by the respondents in a various scale of severity. Most of them were on a mild scale. It indicates that the respondents feel the complaints only once in a while and it doesn't bother their daily activities. Different from that, the respondents who experienced hot flushes and sweating which is included into some-vegetative symptoms in severe scale (36.1\%). As a result, it affected their activities and sleep qualities. Moreover, small 
numbers of respondents had experienced the complaints of those three dimensions in very severe scale so that it bothers respondents' activities.

\section{Categories of Women' Perception toward Signs and Symptoms of Menopause}

This section presents the respondents' perception toward signs and symptoms of menopause. It is categorized as positive and negative perception.

Table 6 Category of Respondents' Perception toward Signs and Symptoms of Menopause

\begin{tabular}{|c|c|c|c|c|}
\hline \multirow{2}{*}{ No } & \multirow{2}{*}{ Assessment Aspects } & \multirow{2}{*}{ Category } & \multicolumn{2}{|c|}{ Signs and Symptoms } \\
\hline & & & Frequency $(\mathbf{n})$ & Percentage (\%) \\
\hline \multirow{2}{*}{1.} & Hot flushes and sweating & Positive & 52 & 53,6 \\
\hline & & Negative & 45 & 46,4 \\
\hline \multirow[t]{2}{*}{2.} & Heart discomfort & Positive & 11 & 11,3 \\
\hline & & Negative & 86 & 88,7 \\
\hline \multirow[t]{2}{*}{3.} & Sleep problems & Positive & 24 & 24,7 \\
\hline & & Negative & 73 & 75,3 \\
\hline \multirow[t]{2}{*}{4.} & Depressive Mood & Positive & 12 & 12,4 \\
\hline & & Negative & 85 & 87,6 \\
\hline \multirow[t]{2}{*}{5.} & Irritability & Positive & 11 & 11,3 \\
\hline & & Negative & 86 & 88,7 \\
\hline & Anxiety & Positive & 19 & 19,6 \\
\hline & & Negative & 78 & 80,4 \\
\hline & Physical and mental & Positive & 26 & 26,8 \\
\hline & exhaustion & Negative & 71 & 73,2 \\
\hline & Sexual problems & Positive & 13 & 13,4 \\
\hline & & Negative & 84 & 86,6 \\
\hline & Bladder problems & Positive & 16 & 16,5 \\
\hline & & Negative & 81 & 83,5 \\
\hline & Vaginal dryness & Positive & 10 & 10,3 \\
\hline & & Negative & 87 & 89,7 \\
\hline & Joints and muscular & Positive & 44 & 45,4 \\
\hline & discomfort & Negative & 53 & 54,6 \\
\hline
\end{tabular}

Generally, respondents had negative perception toward signs and symptoms of menopause except on hot flushes and sweating' aspect. They tended to have a positive perception $(53.6 \%)$ toward it. However, $45.4 \%$ of the respondents had positive perception toward joints and muscular discomfort.

The respondents' negative perception toward signs and symptoms of menopause showed that the respondents don't have comprehensible knowledge related to the signs 
and symptoms of menopause. Whereas, the respondents' awareness in recognizing the signs and symptoms of menopause is expected can control varied complaints which occur in mild, moderate, severe, and very severe level, and give the ability for the respondents to be able to adapt to their elderly time. Besides, women need to utilize health care to overcome any complaints which are caused by signs and symptoms of menopause and also follow elderly health programs.

\section{CONCLUSION}

The respondents experience some signs and symptoms namely hot flushes and sweating, heart discomfort, sleep problems, depressive mood, irritability, anxiety, physical and mental exhaustion, sexual problems, bladder problems, vaginal dryness, joint and muscular discomfort. The symptoms are felt at the varying level of severity and include all three dimensions. Most of the respondents feel hot flushes and sweating at different levels of severity. The most severe symptom experienced by the participants is joint and muscular discomfort. The three dimensions of menopause's signs and symptoms are experienced in different scale but generally, it is felt on a mild scale. Most of the respondents have a negative perception toward 10 out of 11 of menopause's signs and symptoms.

\section{REFERENCES}

Andrews, Gilly. (2010). Buku ajar kesehatan reproduksi wanita (women's sexual health). Ed.2. Jakarta : EGC.

Ayu Chandranita, Ida. (2009). Memahami kesehatan reproduksi wanita. Jakarta. Buku Kedokteran.

Greene, JG. (2002). Measuring the symptom dimension of quality of life: General and menopause-specific scales and their subscale structure. In: Hormone replacement 
therapy and quality of life. London, New York, Washington : The Parthenon Publishing Group.

Heffner Linda J., Danny J. Schust. (2006). At a glance system reproduction. Jakarta: Erlangga

John Londono, Paula Valencia, Anna Maria Santos, Luisa F.G, Roberto B, Rafael V.O, (2013). Risk factors and prevalence of osteoporosisin premenopausal women from pooreconomic backgrounds in Colombia. Dovepress . 5.425

Kristiyanasari, Weni. (2010). Menopause dan sindrom premenopause.Yogyakarta : Nuha Medika.

Kusmiran, Eny. (2011). Kesehatan reproduksi remaja dan wanita. Jakarta : Salemba Medika.

Lestary, Dwi. (2010). Seluk beluk menopause. Yogyakarta : Graha Ilmu

Lunetta Yoshe. (2012). Peranan penting serotonin dan kaitannya dengan stress. Diambil pada 14 Juni 2016 dari http://informasitips.com

Ngastina. (2013). Menopause dini. Diambil pada 8 Februari 2016 dari https://anfieldcuncen.wordpress.com

Notoatmodjo, Soekidjo. (2010). Metodologi penelitian kesehatan. Jakarta : Rineka Cipta.

Proverawati, Atikah. (2010). Menopause dan sindrome premenopause. Yogyakarta : Nuha Medika.

Rahman, Faizus Salehin, Iqbal. (2011). Menopausal symptoms assessment among middle age women in Kusthia, Bangladesh. BioMed Central. 4. 188.

Rahman, Zainudin S. R., Mun Verna Lee. (2010). Assessment of menopausal symptoms using modified Menopause Rating Scale (MRS) among middle age women in Kuching, Sarawak, Malaysia. BioMed Central.9. 5.

Ronny Ardi. (2013). Penyakit jantung koroner pada perempuan. Diambil pada 14 Juni 2016 dari http://gosehat.com

Santhi Vadugu, Vani Lanke. (2015). The menopause rating scale (Mrs) in Indian women. Journal of Evidence based Medicine and Healthcare.2. 8790.

Sastrawinata. (2008). Obstetri fisiologi. Bandung: Bagian Obstetri \& Ginekologi FK Universitas Padjadjaran: 153-159.

Sibagariang, Eva Ellya, dkk. (2010). Kesehatan reproduksi wanita. Jakarta. Trans Info Media. 
Senolinggi, M.A., Mewengkang, M., Wantania, J. 2015. Hubungan antara usia menarche dengan usia menopause pada wanita di Kecamatan Kakas Sulawesi Utara tahun 2014. Jurnal e-clinic (eCI), Volume 3, Nomor 1, Januari-April 2015.

Triana, Rostiana. (2009). Kecemasan pada wanita yang menghadapi menopause [skripsi]. Depok : Fakultas Psikologi, Universitas Gunadarma.

Zeg Berlin. (2008). MRS-The Menopause Rating Scale, Developed By The Berlin Center For Epidemiology and Health Research. Diambil pada 14 November 2015 dari http://www.menopause-ratingscale.info/evaluation.htm. 